Research, part of a Special Feature on New Methods for Adaptive Water Management

\title{
Assessing the Resilience of a River Management Regime: Informal Learning in a Shadow Network in the Tisza River Basin
}

\author{
Jan Sendzimir $^{1}$, Piotr Magnuszewski ${ }^{1,2}$, Zsuzsanna Flachner $^{3}$, Peter Balogh $^{4}$, Geza Molnar $^{5}$, \\ $\underline{\text { Attila Sarvari }}^{6}$, and Zsuzsanna Nagy ${ }^{7}$
}

\begin{abstract}
Global sources of change offer unprecedented challenges to conventional river management strategies, which no longer appear capable of credibly addressing a trap: the failure of conventional river defense engineering to manage rising trends of disordering extreme events, including frequency and intensity of floods, droughts, and water stagnation in the Hungarian reaches of the Tisza River Basin. Extreme events punctuate trends of stagnation or decline in the ecosystems, economies, and societies of this river basin that extend back decades, and perhaps, centuries. These trends may be the long-term results of defensive strategies of the historical river management regime that reflect a paradigm dating back to the Industrial Revolution: "Protect the Landscape from the River." Since then all policies have defaulted to the imperatives of this paradigm such that it became the convention underlying the current river management regime. As an exponent of this convention the current river management regimes' methods, concepts, infrastructure, and paradigms that reinforce one another in setting the basin's development trajectory, have proven resilient to change from wars, political, and social upheaval for centuries. Failure to address the trap makes the current river management regime's resilience appear detrimental to the region's future development prospects and prompts demand for transformation to a more adaptive river management regime. Starting before transition to democracy, a shadow network has generated multiple dialogues in Hungary, informally exploring the roots of this trap as part of a search for ideas and methods to revitalize the region. We report on how international scientists joined one dialogue, applying system dynamics modeling tools to explore barriers and bridges to transformation of the current river management regime and develop the capacity for participatory science to expand the range of perspectives that inform, monitor, and revise learning, policy, and the practice of river management.
\end{abstract}

Key Words: flooding; floodplain; regime shift; resilience;Tisza River; transformability.

\section{INTRODUCTION}

Uncertainty from decades of ecological, economic, and social decline, punctuated by extreme events such as flooding, water stagnation, and toxic spills, weighs heavily on rural river regions in Central Europe, especially in the Hungarian reaches of the Tisza River Basin (HTRB). Many river communities share an uneasy anticipation of future change, even as regional decline makes some change seem inevitable and necessary. This sense of threat is deepened by uncertainty introduced from larger scales, such as climate change and the global reach of economies and politics. Uncertainty is also fueled by national suspicions that river management is trapped in a hopeless downward spiral of coping reactions that never build enough initiative to adapt and improve the situation (Sendzimir and Flachner 2007). Uncertainty gained an ironic twist from a vague sense of regularity in the familiar rhythm of these cycles of crisis and coping response. Over the past decade the public sense of risk and vulnerability has surged as sharp rises in flood intensity and frequency in the HTRB have brought this rhythm to a critical pitch. River management in the HTRB appears caught in a trap marked by the relentless return of increasingly urgent crises that each previous response promised to fix. 
For several decades, a "shadow network" (Olsson et al. 2006) of scientists and local activists both in and outside of government has slowly grown in Hungary around a distributed set of dialogues to understand this management trap and how it is perpetuated by the links that reinforce the current river management regime (RMR). This loose alliance, perhaps a network of networks, of government agents, local activists, and scientists is informal in the sense of providing alterative visions and methods, supported with field experiments, to those that dominate the national agenda. Membership reaches into the higher realms of government ministries, but water policy has not yet shifted substantially. Most water management actions still reflect the fundamental paradigm: "Protect the Landscape from the River," that drove the river engineering dynamo at the heart of the conventional RMR. Water policy emanates from Budapest to control the vagaries of water and society from the top, rather than from a proactive attitude boldly embracing the lessons of the bottom, e.g., multiple experiments and perspectives that put that paradigm at risk throughout a network distributed along the Tisza.

Although tolerated by the river authorities of the current RMR that runs and shapes the HTRB, this dialogue is spreading beyond the shade of national neglect. Scientists outside Hungary are joining, attracted by opportunities to learn from the richness of perspectives and innovative ideas on river management in the shadow network, some of which are or will soon be tested in field experiments on the HTRB floodplain (Molnar 2003, Sendzimir and Flachner 2007). The potential for innovation seems to have spread beyond scientists and activists to the general public. Years of discussion across all levels of Hungarian society have generated sufficient trust and readiness to consider and support new approaches, and this increase in social capital makes surprising reversals of initial policy successes, (policy resistance sensu Sterman 2000) less likely. To be sure, this is still a minority view, but a growing one.

This paper reports on how two groups joined as an international work team in a common effort to escalate one informal dialogue in the shadow network into an adaptive learning process (PahlWostl et al. 2007, Sendzimir et al. 2007). The Hungarian members of the team have been key contributors to long-standing dialogues in the shadow network and the resulting experimental atmosphere in Hungary. The Austrian and Polish team members brought concepts such as resilience, adaptive capacity, and vulnerability, and conceptual modeling tools to help assess different perspectives on how to address the management trap of deepening shocks amidst chronic regional stagnation and decline. Over the past $2 \mathrm{yr}$ the author team met alone and with other stakeholders at national, regional, and local levels, e.g., officials from local, regional, and national authorities, NGOs, scientists, in a series of scoping workshops in Hungary. Using conceptual modeling to focus discussion, we began by defining diverse perspectives on the reasons for regional decline under the current RMR as a prelude to assessing the barriers and bridges to transformation to a more flexible and adaptive river management regime in the HTRB. In particular, we confronted the question of how the current RMR might shift to more exploratory strategies based on a paradigm: "Live in Harmony with the River" that adapts user functions to the natural environment and not visaversa (Smits et al. 2000). Innovations recommended by the shadow network might provide the basis for substantial policy change, if not regime change, in an integrated water and land management regime.

Walker et al. (2004) proposed transformability to describe the potential to create an entirely new system, to deliberately shift from an undesirable current attractor to a new one with a new stability landscape. Olsson et al. (2006:2) elaborated transformability as the capacity to define and create "novel system configurations by introducing new components and ways of governing socialecological systems (SES), thereby changing the state variables, and often the scales of key cycles, that define the system. Transformations fundamentally change the structures and processes that alternate feedback loops in SESs." For shadow networks a critical initial step toward full commitment is to assess the feasibility of transformation (Olsson et al. 2006, Gunderson 1999, 2003). Is there sufficient adaptive capacity and integrity within the SES to support navigation of the turbulent waters from one management regime to another? Our consideration of transformability embodied this question.

The goal of this paper is to present insights into the factors that support or block transformation from a conventional RMR, which reflects the historical default to the industrial paradigm, to an adaptive RMR in the Hungarian HTRB. A secondary goal is to show how participatory modeling methods enrich 
understanding into transformability. The methods section gives an overview of participatory modeling and the study area, the HTRB, with special regard for some of the historical trends that contributed to the current socio-environmental context. The results section first assesses some of the major barriers and bridges to transformation to a new management regime in the HTRB, and then uses conceptual models developed in our informal dialogue to examine some of the structural mechanisms underlying some of the key barriers and bridges. In the discussion, we compare different factors that support transformability as found in other SES as well as the HTRB, and we critically examine the dialogue process itself. The conclusion summarizes the main lessons learned.

\section{METHODS}

\section{Group participatory modeling methods}

Any research based on unreplicated observations from a single case study requires careful attention to the validity and generality of its conclusions. This is even more important if "hard data" about the investigated system are missing, which is often the case in complex and evolving social-ecological systems. Traditional criteria for the natural sciences, i.e., positivist social sciences of reductionism, repeatability, and refutation (Checkland 1981), are not possible to apply in situations in which the rules, or causal relations, are not homogeneous through time (Keynes 1938), and controlled experiments are too expensive or unethical. Unfortunately, many important questions are never asked when the research context does not meet such criteria. However, alternative methodologies have been developed to address such fluid situations. When applied in an appropriate and rigorous manner, participatory research processes, such as action research (Eden and Huxham 1996, Whyte 1991) or adaptive management (Gunderson et al. 1995), can reflexively integrate science, policy, and local practice. Checkland and Holwell (1997) suggested that instead of the replicability criterion, which can be used in research in which the system can be controlled, an alternative criterion, i.e., recoverability, does a better job for investigating larger-scale, volatile human and social phenomena. The main idea is to "enact a process based on a declared-inadvance methodology, encompassing a particular framework of ideas in such a way that a process is recoverable by anyone interested in subjecting the research to critical scrutiny" (Checkland and Holwell 1998:18). This approach makes it possible to replace hypothesis testing with investigating research themes, with which certain lessons can be learned. This is necessary in many messy situations (Vennix 1999, Rittel and Webber 1973), in which it is not obvious what is the problem and for whom (Checkland and Scholes 1990).

In our research in the Hungarian reaches of the Tisza River Basin (HTRB), we decided to use conceptual system dynamics as our "declared-in-advance" methodology (Vennix 1995, Sterman 2000) to explore the worldviews of one subgroup of stakeholders. We used tools such as causal loop diagrams and stocks and flows diagrams (Sterman 2000, Magnuszewski et al. 2005, Sendzimir et al. 2007), to focus our group's dialogue on how different patterns of interaction block or assist transformation. Many model-led participatoryscience discussions begin with models that most people are familiar and comfortable with such as narratives, pictures, collages, maps, tables, and lists. Our efforts to extend the dialogue within the informal network began with narratives but quickly moved to conceptual models, as they proved easiest to work with in describing webs of interactions. We do not claim here that developed diagrams (see Results and Appendices 1 and 2) reveal the truth about this system, but with the causal mechanisms we present all steps of reasoning and assumptions contributing to this particular worldview. This helps to understand the driving forces of the shadow networks, which are often hidden in their mental models, striving to transform the HTRB and can also be a first step to a dialogue of a more diverse group of stakeholders.

Parallel declines of the ecological, economic, and social sectors (see Appendix 3) of the HTRB suggest links that have so far eluded the perspective of any single discipline. Assessing the structural ties underlying those declines and the potential for transformation requires scrutiny both within and across those sectors. The need for multiple perspectives arises not only from the complexity of cross-scale interactions out there but also from the diversity of framings and mental models (DeWulf et al. 2007) people use to construct their separate views of the system (see Thompson et al. 1990, Thompson 1997 for one example of a typology of mental models). System dynamics approaches can be used in a group model-building mode (Vennix 1996, van der Belt 2004) offering a range of tools 
to elicit and elaborate the diversity of perspectives stakeholders bring to a participatory learning process.

\section{Study area: The Tisza River Basin}

Some of the most dramatic flood dynamics in Europe occur at the sharp transition between the relatively short but steep Carpathians and the vast alluvial Hungarian plain (Fig. 1). The Tisza River, one of the larger tributaries of the Danube, can rise more than twelve meters within $24 \mathrm{~h}$ following major rain events in the mountains of the western Ukraine and Romania (BME ViKöK 2003, Sendzimir et al. 2004). Surprise can surge to shock when such flood waves, or industrial accidents alone, precipitate toxic spills of heavy metals and cyanide (Souren 2000, Vituki 2000) devastating riverine fauna, especially fisheries, and depressing regional tourism. Heavy metal accumulations in river bottom sediments constitute a time bomb that acid spills or prolonged hypoxia could mobilize.

In contrast to the dynamic optimism of modern cities where most change is welcomed as stimulating novelty and a productive catalyst for business and culture, uncertainty underlies an uneasy anticipation of the future in many communities in the HTRB. This chronic sense of uncertainty is stoked by a long slide into rural decline as small town populations drain out of the region into major urban centers in Western Hungary or elsewhere in Europe and beyond. Major flood catastrophes have punctuated a long chain of local crises: closing businesses, schools, libraries, medical clinics, and other services. Trends of stagnation or decline in the ecosystems, economies, and societies of the HTRB extend back decades, and perhaps, centuries (Molnar 2003, see Appendix 3).

In the HTRB, extreme floods occur on average every 10-12 yr (BME ViKöK 2003), but the last century has seen rising trends in all facets of flooding: peak elevation, volume, frequency, and especially, damages (Sendzimir et al. 2004). Current river defense infrastructure has repeatedly failed to protect against the shock of major flood waves or the chronic stress of water stagnation following minor floods, e.g., dikes overtopped, and groundwater upwelling in fields, even if dikes remain intact. Water accumulation over large areas, e.g., 400,000 ha in $1 \mathrm{yr}$ alone, can damage houses, infrastructure, and crops, and annual costs for damage and avoidance procedures such as pumping can total as much as $10 \times 10^{9}$ forints $\left(\$ 40 \times 10^{6}\right)$ (Hungarian Ministry of Agriculture and Rural Development 2006, Nagy et al., unpublished data).

The roots of these increasing flood statistics may lie in a series of hydro-engineering operations that massively reconfigured the river basin starting in the 18th century (Fig. 2). Expansion of empire, industry, and urban populations required substantial increases in grain production and transport. Frequent armed conflict mandated that standing armies be continuously sustained, and grain fueled both foot soldiers and, critically, horse-borne cavalry. The Austrian and Hungarian aristocracy seized this opportunity by modifying the Tisza River Basin morphometry to fit socio-political demands for grain production and export, habitation, and flood protection. During that era these production imperatives enshrined the motivating paradigm "Protect the Landscape from Water" for what became the conventional river management regime (RMR) that shifted control from local communities to Budapest. The river was deepened to hasten water flow and expedite barge transport, shortened by $400 \mathrm{~km}$ to facilitate export from the northern part of the HTRB, and bracketed with dikes to prevent flooding of grain fields and habitations.

Initial demands to facilitate barge transport raised earthwork towpaths along the main river channel margins that eventually closed all the notches by the late 18th century, effectively cutting or severely reducing connectivity between the river and floodplain. Notches refer to the openings on the river margins that controlled connectivity between the channel and the floodplain in a preindustrial Hungarian water "steering" system (Fodor 2005). Local floodplain farmers began complaining to the Emperor after lack of hydraulic connectivity led within decades to water stagnation damage and plummeting productivity. At the beginning of the 19th century, these demands were ignored as the accelerating Industrial Revolution concentrated increasing urban populations around factories created an exploding market for bread in European cities. Furthermore, an emerging stratum of minor nobility began to displace local farmers as their war contributions were rewarded with floodplain land grants, and they fueled their upward trajectory with that era's most profitable production strategy: replacing a fruit/nut/fishery polyculture with grain monocultures (Sendzimir and Flachner 2007). 
Fig. 1. Topographic scheme of the Tisza River Basin. The Carpathian Mountains form an arc along the north and east from which the Tisza and all its tributaries flow to the west and south over the flat Hungarian Plain, eventually joining the Danube River in the Republic of Serbia (from Jolankai and Pataki 2005).

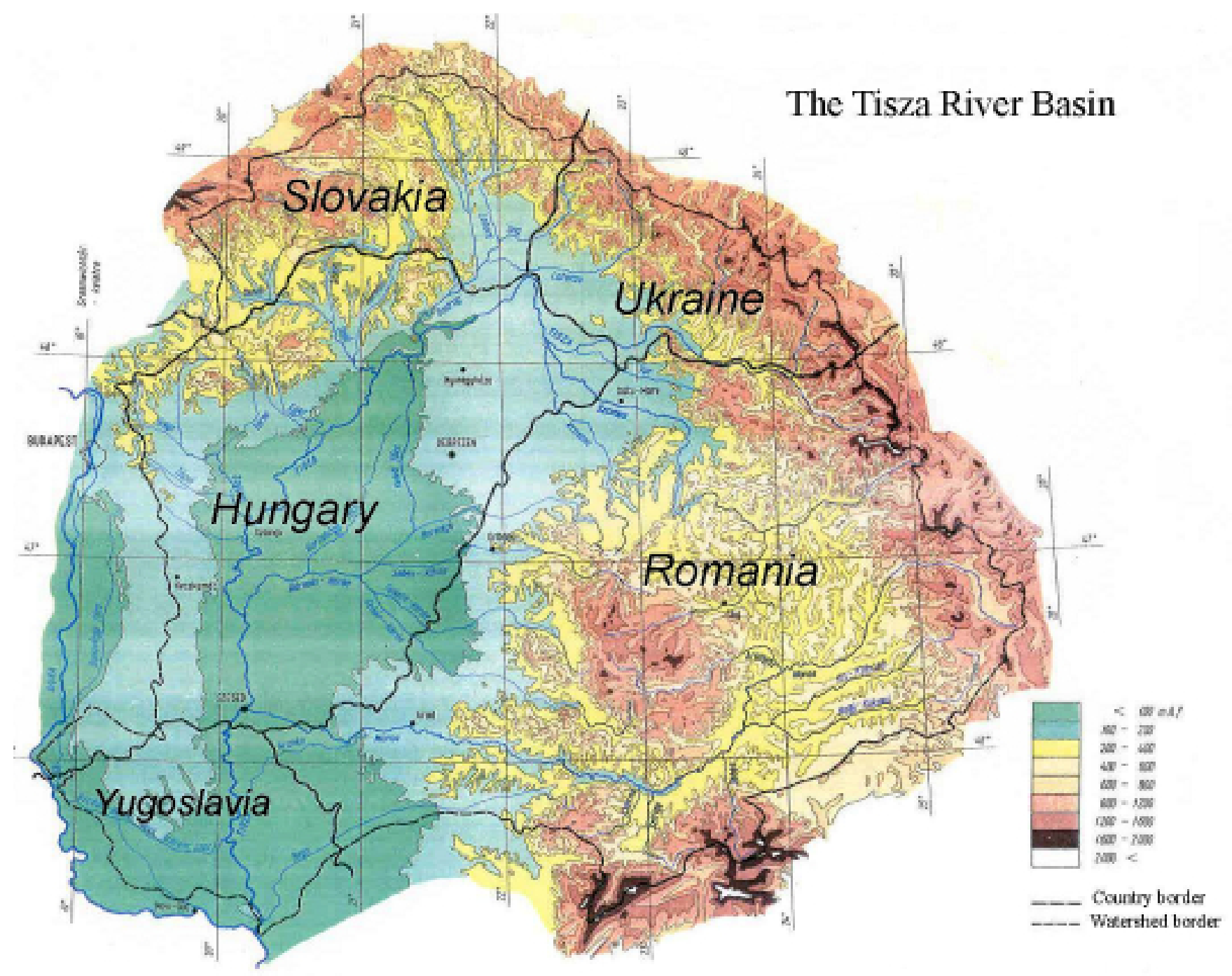

These minor nobles used their increasing political and financial capital to organize local peasants into work teams that built and repaired the dike and drainage systems.

By the late 19th century, the accumulating problems of water stagnation, lost productivity, and rising flood trends reached crisis proportions, provoking basin-wide re-engineering under the original Vásárhelyi Plan (Molnar 2005, Sendzimir and Flachner 2007). This plan began a process that over a century eventually protected $97 \%$ of the basin at risk from flooding with over $4500 \mathrm{~km}$ of primary and secondary dikes along the Tisza and its tributaries. This also consisted of embankments around some 840 smaller settlements and circular levees around 48 cities and large villages (Siposs and Kis 2002). In addition, some $40,000 \mathrm{~km}$ of canals were added to decrease the groundwater levels and hasten drainage of wheat fields and support irrigation (Szlávik et al. 2003). 
Fig. 2. Artist's interpretation of different landscape mosaic patterns in the Tisza River floodplain both pre- (a) and post- (b) execution of the original Vasarhelyi River engineering plan in 1871. (with permission from Siposs and Kiss 2002 WWF Hungary).

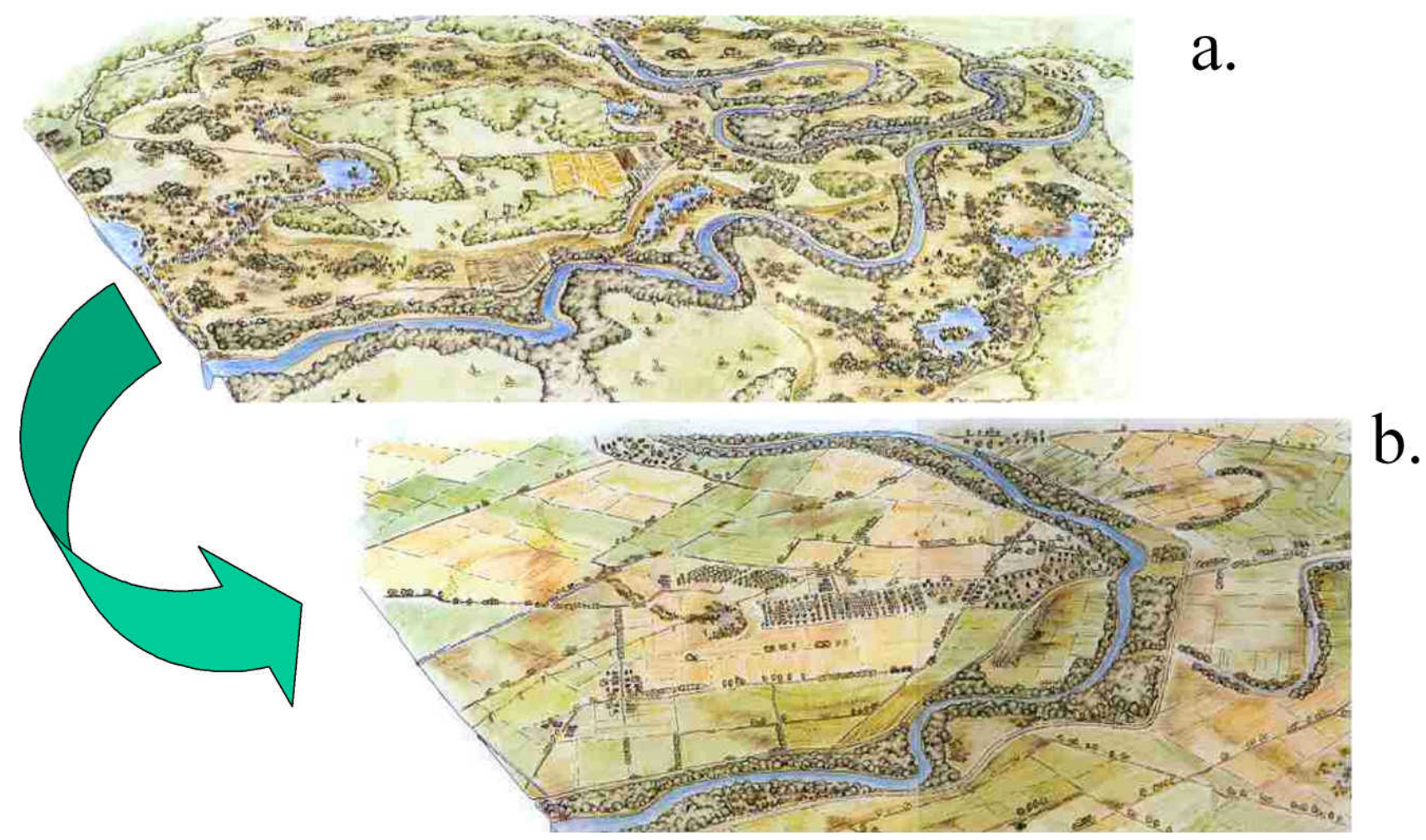

Spectacular advances in science, medicine, and industry stoked a vision of industrial optimism that framed popular understanding of flood crises and rural decline for two centuries in the HTRB. These crises were seen then as but the messy residue of society realigning itself for a more productive future. Industrial progress would eventually contain extremes of nature and uplift all economies, even the rural poor. Failure to deliver on this promise became evident in the last few decades of the 20th century as the interval between ever more severe crises decreased. Public discussion around this growing recognition of the management trap rarely escaped fruitless cycles of political finger-pointing. Explaining mysterious events by blaming individuals (Tetlock 1985), or in this case, government, is a common initial reflex. On average residents in the HTRB still see government as the prime actor responsible for management and safety (Flachner and Németh 2006, Linnerooth-Bayer and
Vari 2006, Linnerooth et al. 2006). However, no particular government, e.g., actor, network, or political philosophy, has consistently been at the helm. The pattern underlying this trap extends for more than two centuries across wars, monarchies, socialist empires, and emerging democracies. If we look beyond any single clique of usual suspects to blame, then what forces and factors consistently interact to sustain such the trap of chronic regional decline?

The concomitant decline of ecological, economic, and social systems in the HTRB suggests that they are linked with agents of governance in a web of interactions. In contrast to the popular characterization of a regime as a political elite, such a constellation of feedbacks reinforcing the basins' paradigms, policies, practices, and technologies, actors and organizations might be a more comprehensive view of the management regime that directs the structure 
and function of the HTRB (Pahl-Wostl et al. 2007). This wider view may capture more of the important variables, but it raises the bar, challenging us to sort out how they add up such that a river management regime (RMR) sets the basin's trajectory.

\section{RESULTS}

At river basin scales, concepts such as resilience, vulnerability, or adaptive capacity represent aggregate behavior emerging from a confusing diversity of factors and pathways. These concepts became more practical when our group narrowed the focus of our investigation down to transformability from the conventional river management regime (RMR): operative paradigm "Protect Landscape from the River" to an Adaptive RMR: operative paradigm "Live in Harmony with the River." Both of these regimes are conceptualized as valleys, i.e., stability domains, in a stability landscape (see Fig. 3). The conventional RMR industrialized the Hungarian reaches of the Tisza River Basin (HTRB) by adding structures, including dikes and large-scale monoculture that seem increasingly vulnerable to extreme events (Sendzimir et al. 2004, Sendzimir and Flachner 2007), so our team's dialogue explored transformation scenarios that establish new regimes (Adaptive RMR) with capacities that include fundamental redesign of the HTRB, e.g., removing or modifying these current structures and the processes that reinforce them. We use the term transformation to signify the shift from the current RMR to an adaptive one that is resilient to global sources of uncertainty because extremes such as droughts, floods, water stagnation, and economic volatility would no longer threaten the integrity of nature or society. We first analyze some of the main barriers and bridges, abbreviated as Bar and Bdg, respectively in Table 1 and the subsequent text, to a transformation trajectory for the current RMR from a conventional to an adaptive stability domain and then examine specific mechanisms with conceptual models (in this Section as well as Appendices 1 and 2).

\section{Bridges}

Transformation may arise less from convergence of separate, parallel elements than from a chain or cascade of thresholds (Kinzig et al. 2006), where each threshold passed triggers the accumulation toward the next. Such a cascade may have started in the HTRB with a recent series of flood crises that radically changed public perception (Bdg 1$)$ and debate of flood risk management. Rising trends in flood frequency and intensity became undeniable when a rash of flood emergencies in the late 1990s (Bdg 4) finally convinced the national government that conventional flood defenses could not keep up with such increasing challenges. The density of the underlying substrate limits how high dikes can be built, the national budget limits how often, and elected officials are keenly aware of political capital lost when floods devastate communities. Loss of life due to dike failure can trigger a swift route to severe penalties such as fines, job loss, and even jail for river managers, but stopgap reinforcement of infrastructure no longer guaranteed safety.

These recent flood crises may have amplified a negative impression of the Hungarian water management establishment, which suffered a grave loss of national confidence when their defense, sustained throughout the 1980s, of the GabcikovaNagymaros dam project on the Danube grossly underestimated the environmental and political costs (Deets 1996, Fitzmaurice 1996, Smith et al. 2000). At the same time, the transition to democracy shifted the central political paradigm from command-and-control toward decentralization, denying river managers and national policy makers much of the initiative to independently design and impose management strategies that they had enjoyed under socialism. Wavering support for conventional flood management policy opened the door to alternative visions emerging from the shadow network, some elements of which had coalesced originally around opposition to the Gabcikova dam project but were not directly connected to the HTRB. Decentralization also enabled some policy actors the freedom to decouple from and then recouple (van Eeten and Roe 2000) to national planning, by independently setting strategies and then re-engaging other actors to synthesize integrated management plans. By the mid-90s, key factions within nature conservation and water management started to cooperate, launching the Green Corridor program (L. Haraszty, personal communication). The emergence of local and regional actors with alternative ideas and programs began to challenge the dominance of national decision makers, their methods and conceptual foundation: the conventional river management paradigm that river flood pulses and flows over the landscape must be prevented. 
Fig. 3. Alternative management regimes for the Tisza River Basin. Adaptive river management regime (RMR) and Conventional RMR are conceptualized as stability domains. The current RMR, represented by a ball, shows an actual state of the system in transformation.

\section{Adaptive RMR Conventional RMR

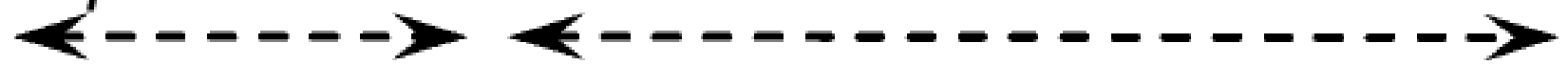

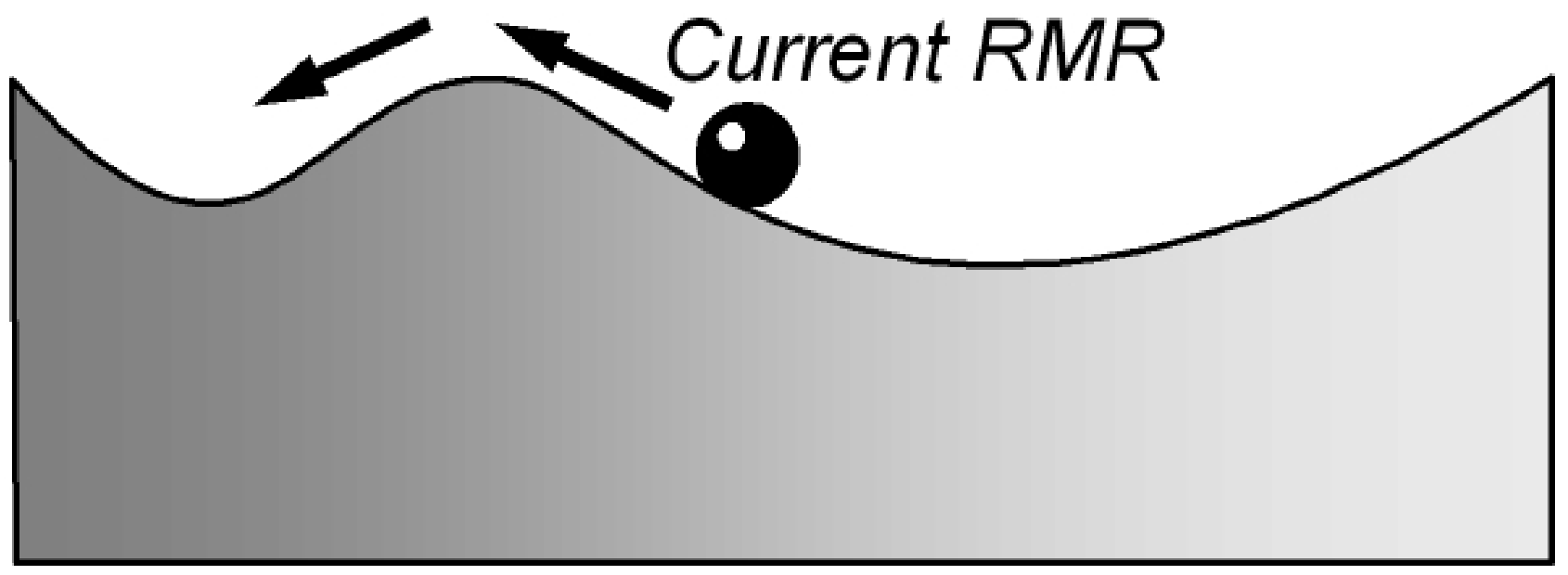

Caught between crumbling support at home and uncertainty from climate change, and EU regulation and international investment from abroad, national water authorities began to show unprecedented flexibility in considering the future development of the HTRB. Public and professional debate for the first time began to include alternative management options (Bdg 1). One alternative, to use the floodplain outside the dikes to store water in a flood emergency, had invariably been trumped by the dryland requirements of grain production: the motive force behind the conventional RMR paradigm that has driven HTRB development for the past two centuries. However, the shadow network (Bdg 3) had fomented new floodplain management ideas (Bdg 7), and their dissemination (Bdg 9) boosted pressure for alternative approaches soon after recent flood crises in 1997, 1999, 2000, and 2001 exposed the weaknesses of conventional management approaches.

The shadow network's dialogue resonated with German successes in using dry polders for flood storage on rivers such as the Elbe (Kundzewicz et al. 2005) and with Dutch recognition (Smits et al. 2000) that the current RMR operates from a paradigm: "Protect the Landscape from Water" that evolved over centuries of reshaping the basin to suit human needs such as transport and grain production. If industrial power could not keep up with increasing trends of river flood pulses perhaps our ingenuity should work with rather than against such processes. This commitment to respond flexibly informs a new paradigm: "Living with the River" that increases the range of functions river management policies support from transport and flood defense to include ecosystem services on which biodiversity and extensive land practices rely. Increasing acceptance and use of this paradigm in the Netherlands and Germany provides (Bdg 7) compelling examples for informal and formal dialogues among inhabitants and managers of the HTRB as well as Hungary as a whole. These ideas have cascaded up to Brussels and have influenced efforts to reform agriculture (Common Agricultural Program or CAP) and water (Water Framework Directive) policy (Bdgs 6 and10). Available online at: http://ec.europa.eu/agr iculture/capreform/index en.htm. 


\section{Table 1. Summary of major barriers and bridges to transformation of the Hungarian reaches of the Tisza} River Basin (HTRB); not in order of importance or priority.

Barriers arising from the current system

Basis: Long Established Paradigm

"Protect Landscape from the River"

Bar 1: Centuries living behind dikes entrenches a defensive mentality based on fear of water.

Bar 2: Sunk costs of massive infrastructure investment over two centuries inhibit any suggestion to modify or remove that infrastructure.

Bar 3: Momentum of national and globally driven development based on conventional paradigms leading to intensification of agricultural practices.

Bar 4: Lack of access to critical new information due to technological sophistication and due to lack of integration across domains of inquiry, i.e., disciplines, practice, i.e., training, and governance, i.e., government jurisdictions

Institutional Inertia

Bar 5: Concentrated lobbying power of prominent actors, i.e., individuals and organizations with ample financial and political capital, overwhelms dispersed and disorganized local farmers and activists.

Bar 6: System self-organizes around reward loops of subsidies and paybacks, which reinforces a tight elite network such that all funding is funneled into their political machines within the present agricultural regime,

Bar 7: Present institutional structures do not permit implementation of complex, integrated programs that still follow administrative and sectoral lines.

Problems of Transition

Bar 8: Failure to reach and keep consensus. Some particular interests and alliances of the subgroups take overall precedence over solutions agreed upon by all parties

Bar 9: The diversity of views, knowledge, and terminology in all the separate formal and informal networks stall initiatives.

Bar 10: Inertia of passive attitudes by local stakeholders sustained in the absence of leadership to build trust and understanding and motivate action across the region.

Bar 11: Huge investment of financial, political, and social resources needed to provide convincing evidence of benefits of alternative river management strategies.

Bar 12: Loss of natural capital, e.g., biodiversity, seed bank, and human capital, e.g., skills, local knowledge, due to death, termination of local practices, and regional emigration increase initial investments needed to re-establish the functional basis of a sustainable social-ecological systems (SES).
Bridges to an Alternative System

Basis: Emerging New Paradigm:

"Live in Harmony with the River"

Bdg 1: More diverse view of options shared by a wider portion of society, including river engineers that we have to learn to live with a naturally flowing river

Bdg 2: Increasing engagement of leaders and concerned citizens in considering and deciding on alternative management ideas

Bdg 3: Shadow network spanning entire TRB functions to generate new visions that influence regional debate.

Bdg 4: Flood, water stagnation, drought, and political crises shift political climate such that a window for alternative solutions appears in public debate.

Bdg 5: Awareness-raising of importance of local culture, markets, regional brands, etc., and individual responsibility in decisions of where and how one lives.

Bdg 6: CAP reform (2nd pillar) promises new system to subsidze ecological farming and land use change and management practices that boost environmental services.

\section{Demonstrations or Experiments}

Bdg 7: Innovative traditional and novel ideas show promise to concretely address drought and flood volume management as indicated by integrated basin computer models and pilot projects in western Europe and Hungary.

Bdg 8: Legacy of knowledge and experience in extensive land uses and cultivation practices that provide sustenance in a periodically inundated floodplain.

Dissemination

Bdg 9: Information dissemination by civic groups and individuals, facilitated by the shadow network.

Institutional Change

Bdg 10: EU policies (Natura 2000, WFD, CAP reform) create a supporting reference framework with which to examine and modify river management policy. 
Although still incomplete, this emerging vision reinterpreted flood damage from a clarion call to build higher dikes to recognition that new strategies must be sought against the possibility that dike defenses continue to fail, never getting ahead of rising flood trends. The alternative paradigm blossomed in this shifting political climate (Bdg 1 and 4) into a pilot field test of floodplain capacity to buffer flood volumes in the Bodrogköz region of the Upper Tisza (Flachner 2005). For the first time in Hungary, flood crisis inspired redesigning or removing rather than rebuilding dikes, shifting the management strategy from resistance through sheer dike mass to steering the water by operating sluices opening the dikes. Such an alternative strategy would reverse the industrialization of the HTRB by increasing the active floodplain area, which had been reduced $90 \%$ by dikes, to absorb flood volume, lowering flood crest elevation, and velocity and, hence, the vulnerability of built capital such as housing, roads, and utilities and natural capital such as crops and soils developed in the floodplain under the aegis of dike protection.

The shadow network used this opening window (Bdg 1), working with local and national leaders (Bdg 2) to credibly expand the goals of floodplain experimentation from defensive engineering, i.e., flood volume management, to restoration of ecosystem functions at different scales: landscape, including land use and landscape mosaic, fish migration, heat damping, water recharge of deep aquifers, and greenhouse gas amelioration, and habitat, including nutrient cycling, microclimate amelioration, soil formation, and biodiversity maintenance. Often in collaboration with a new wave of activist local government leaders (Bdg 2) civic society, i.e., national and international NGOs, have sustained education and debate campaigns to spread consideration of such innovations across all sectors of Hungarian society (Bdg 9), often integrating it within efforts to revive rural society through re-awakening appreciation for traditional culture (Bdg 8).

Support for floodplains as buffers for water flux increased when hydrological modeling (Koncsos 2006) recently demonstrated (Bdg 7) that only six restored areas, ranging in size from 9000 to 200,000 ha, would be sufficient to handle most flood volumes anticipated in near future climate change scenarios. Moreover, further research suggested that restoration of larger areas ranging up to the entire area that was flood-prone prior to 19th century engineering; the Holocene floodplain, would produce the most engineering and ecological benefits over the long term, i.e., a 100-yr horizon (Koncsos and Balogh 2007, Koncsos and Kozma 2007).

\section{Barriers}

A number of barriers can block transformation simply by restraining capacities to experiment, learn, and develop more adaptive visions and methods for managing the HTRB. Scheffer et al. (2004) posit that in a heterogeneous society with high diversity of experience, training, and beliefs, the challenge of raising public awareness and commitment is increased by problem complexity, peer pressure, and lack of leadership, challenges often evident in rural Hungary. What quality of evidence could pilot experiments provide to overcome these challenges given current riskaverse attitudes (Bar 1, 3, and 10) shared by local farmers and national policy makers? Some farmers still see water as a threat to be shed from the landscape, adhering to the legacy of $150 \mathrm{yr}$ of monoculture and all its guiding paradigms. Others, such as the Slovak minority on the HTRB's northern rim, do not actively resist, but take a "wait-and-see" approach to floodplain re-naturalization experiments. Along the Upper Tisza, farmers of highly productive bottom land show little interest in any floodplain land use alternatives to monoculture (Vari 2006) when the potential for profits remains high (Bar 3). Such inertia may prevent experimentation that is comprehensive enough to drive public commitment to reconfigure the HTRB at scales meaningful to the challenges of global change (Bar 11). Though flooding provokes the most alarm, climate-related intensification of extreme events increases vulnerability by increasing the amplitude of oscillations between the extremes of flood and drought. The same dikes that initially invited floodplain construction which floods then repeatedly devastated also make us more vulnerable to droughts when they shunt water rapidly downstream rather that deposit and store it in the network of ponds, wet forests, and marshes in a broad and spongy floodplain.

Centuries of national investment, i.e., sunk costs, built $4500 \mathrm{~km}$ of dikes in the HTRB, which physically embody the conventional development paradigm that, until recently, has blocked any 
attempt to experiment with alternative water management strategies (Bar 2). Despite recent openness to change among certain actors in the water management sector, as a whole government efforts to integrate understanding and policy are usually fragmented along administrative boundaries between ministries (Bar 7). Communication between agricultural and environmental ministries is strained both in Budapest and in Brussels, providing evidence that political discourse at both national and EU levels rarely relies on integrative, cross-sectoral analysis.

Adaptive capacity declines further when passive barriers of inertia are pathologically reinforced by active investments in projects that further the conventional paradigm. For example, the Hungarian governments' tactics in negotiating with Brussels over farm subsidies within the CAP suggest a conservative bias against reform of agriculture or river management policies. Governments pushing CAP reform, i.e., northern tier nations mostly, such as Germany and Sweden, support the switch from the First Pillar, i.e., market and income support, production, to the Second Pillar, i.e., rural development, especially, environmental services, as the new goal for subsidies (European Commission 2007). By contrast, the Hungarian government not only does not support efforts to implement Pillar II, it subsidizes new equipment purchase programs (Bar 3 and 5) biased toward larger machinery, and hence, larger farms that boost productivity with greater environmental impacts (MAGOSZ 2007).

The same conventional approach to agricultural intensification for higher export earnings (Bar 3) also drives a new initiative to continue and expand on previous efforts to engineer the Tisza basin morphometry to permit more barge transport from Szeged, on the lower Tisza to the Ukraine (VATI 2006). Following EU unification, the increased availability of structural funds for revitalizing Hungary's infrastructure is especially attractive to those well-connected professional organizations with the expertise to farm such subsidies in Brussels. Pouring concrete requires only conventional methods and ideas and returns far swifter and lucrative rewards than the risky business of modifying dikes for uncertain environmental benefits that may emerge years later. The wellcoordinated and concentrated lobbying (Bar 5) of such elite organizations often dominates the wellintentioned but more diffuse efforts of the widely dispersed, loosely organized groups typical of the sustainability activists (J. ángyán, personal communication, Bogár 2007). The latter opened a window to shift strategies to try alternative policies (Bdgs 1, 3, 7, 10), but is it just an environmental frame on business-as-usual?

Regional and local governments often share the same conventional management and development agenda as the higher-level actors with whom they collaborate in sustaining the industrial development trajectory of the HTRB. However, even if they were motivated by alternative development paradigms, they have few financial, social, or political capital resources to counter national and international initiatives, thereby feeding Barriers 3,5 and 6. The power to make and implement decisions has been further centralized in Budapest by the recent funneling of all tax revenues to the administrative summit for national redistribution to districts and localities. The foundations of economic decisions on land use have narrowed with the concentration of $85 \%$ of land holdings in the control of $10 \%$ of the population (Nagy 2006). Following EU unification, collective farms were redistributed into unwieldy jumbles of individual plots, which are often abandoned as noncompetitive in the new market economy. Taking advantage of the disarray of fragmented and abandoned farmscapes, west Europeans, including the Italians, Germans, and Dutch, have exploited long-standing ties with major banks to heavily invest in consolidating individual plots into major land holdings and shift landscape structure, e.g., field size and ownership patterns, toward large-scale intensive agriculture. Such investments count on the large returns of high volume commodity exports produced by intensive technologies and methods. Any attempt to generate new, innovative visions of river management based on local experimentation with nonintensive methods must address this combination of local passive inertia and national active momentum for conventional, industrial development and production in HTRB floodplain communities.

Nonintensive land use practices that are adaptive to extremes of water availability could include the kinds of eco-agriculture, e.g., wet grazing meadows, fish nurseries, fruit and nut orchards, that could boost biodiversity and be profitable in landscapes open to flooding after dike removal (see Fig. A2, Appendix 2). However, such innovations are hindered at all scales. At the local level while social capital has grown slowly after a century of imperial 
(Austro-Hungary, USSR) domination, sufficient passive inertia (Bar 10) remains to hinder local access to information on alternatives (Bar 4) or multiscale experimentation (Bar 11) as well as efforts (Bdg 5) to reduce economic and political pressures from larger-scale Barriers (3, 4 and 5). Examples of the latter are initiatives to start regional or local brands, which do not directly oppose but flank these barriers by creating niches for locally produced foods. Some successes (Váradi 2007) offer refugia where traditional or new alternative practices and local genotypes can survive, but Barrier 10 often keeps any effort to organize cooperatives or brands below the critical mass needed to be sustained. It is hard to develop new enterprises in local communities when a general sense of rural devolution grows as decline of local economies and services force many to move to urban centers (Bar 12). At larger scales, both transboundary initiatives to market regional brands (Bdg 5) and new EU policy initiatives for agriculture and water management (Bdg 10) are isolated interventions from outside Hungary. Their potential to promote sustainable practices has not been woven into the production system in ways that sustain and reinforce them. They fail to gain traction in the face of local passivity (Bar 10), general lack of consensus (Barriers 8 and 9) and failure to integrate across government ministries (Bar 6). Bank investments and subsidies follow the well-worn paths of concentrated lobbying power (Bar 5) and intensive production systems (Bar 3).

A residual core of cultural identity provides a world view that helps some resist this exodus even when they are at an economic disadvantage compared to those who moved to the city. Many of those who remain cultivate and retain their cultural legacy, which includes a seed bank of local fruit and crop varieties and expertise in traditional land practices (Bdg 8; see also Fig. A2). A key challenge is to use this reservoir of knowledge and talent before death and migration (Bar 12) erode it further so as to demonstrate what alternative land uses might work in a renaturalized floodplain. The scale of investment needed to make renaturalization a compelling management strategy for the entire HTRB is unknown but appears huge (Bar 11). Even if benefits are evident beyond mere flood management in the Bodrogköz pilot experiment (Flachner 2005), can such a modest scale demonstration convince the region? Gaining sufficient floodplain area will require significant land use changes, perhaps 9000 to $200,000 \mathrm{ha} /$ experiment, in multiple communities up and down the Tisza. How long will it take for all the productive factors such as flood pulse nutrient cycles, fish communities, animal migration routes, and orchards to mature such that floodplain communities selforganize into a new configuration? The time span needed is probably a multiple of most political cycles, requiring sustained efforts to secure political and financial support in a shifting political landscape. Current pilot experiments show that the political climate has shifted and opened the door to new ideas, but will that momentum be sustained long enough to overcome Barriers 4, 8, 10, and 12 ?

Continental initiatives designed to integrate EU policy make it likely that alternative visions will soon be meaningfully incorporated in the national debate about future river management. The Water Framework Directive of the EU (Bdg 10) requires that all river basin managers use participatory processes that develop management plans for their basins by the year 2009. In Hungary such participatory processes will likely engage some scientists and activists from the shadow network (Bdgs 3,9), thereby expanding the range of concepts and methods integrated in river management plans and potentially increasing adaptive capacity. Similarly, through CAP reform the EU also opens the door to alternative land uses on the floodplain by shifting subsidies from production (CAP First Pillar) to environmentally friendly practices (CAP Second Pillar).

Our survey above lightly skims the shadow network's knowledge pool for some of the key factors that currently open or block opportunities for transformation. However, turning opinion toward transformation requires better insight into the causal links between ecological, economic, and sociopolitical sectors that sustain the current regime. In a group effort, we developed a family of causal-loop diagrams to explore those links. Although the scope of this article does not allow us to present all of them, we explore one below as an example of how these barriers and bridges emerge from interactions within and between these sectors. Two other diagrams depict causal structures underlying the functioning of intensive and extensive agriculture in the HTRB (see appendices). 


\section{Modeling structural relations that bridge or block transformation}

The informal network's dialogues have generated a significant store of goodwill in the HTRB by building trust and understanding as it develops new nodes in the network that share a common vocabulary. However, all these factors have yet to coalesce into a single, comprehensive, and convincing vision. The diversity of alternative explanations continues to overwhelm understanding, fragmenting opinion, and stalling initiative. This failure to unite and rally stakeholders around an alternative story is a key barrier to transformation (see Bar 7 and 8, Table 1). These barriers are reinforced by the lack of any clearly recognized leader (Olsson et al. 2006) to forge such a vision, build links into social networks and lead a sustained debate that institutionalizes social memory and rallies society to action. Such a unifying vision would greatly help our groups' efforts to build such networks, including more Tisza River communities in our search to gain and spread understanding into how to reverse regional decline. In this section we describe how we used group model-building exercises to expand our dialogue, moving beyond "laundry lists" of factors to look at the web of interactions underlying complex behavior. For clarity we confine our observations to those parts of the models that elaborate hypothetical causal structures influencing the barriers and bridges listed in Table 1.

Many of the factors influencing transformation can be clustered into four principle groups, enclosed in boxes in Fig. 4, which represent sets of interactions that persistently reinforce key paradigms and their associated processes. As we describe below, this pairs for the most part the emerging paradigm "Live in Harmony with the River" with Landscape Productivity and the conventional paradigm "Protect Landscape from the River" with Agricultural Intensity. Since the latter two currently dominate HTRB dynamics we begin by describing the key links that drive interactions within and between them. These links create loops reinforcing the conventional RMR.

Two reinforcing feedback loops (R1a, R1b) drive the current spiral of growth in Agricultural Intensity. Increases in per ha Profits on Big Farms boost Intensification Pressure, which drives either further land acquisition to increase Area for Intensive Use or investments in Agricultural Technology that support more intensive uses, e.g., larger and more powerful machinery, chemicals, and fertilizers. These investments increase Crop Yield on Big Farms, which in turn drive higher profits. Either growth cycle might be tempered by a balancing feedback loop (B1), which links the effects of investments of higher profits, i.e., increases in area and value of crops at lower elevations in the floodplain, with higher Crop Damage by Flood, which in turn lowers yields and, ultimately, profits. However, B1's potential to temper growth is neutralized by a reinforcing loop (R2) that links higher profits with either of two drivers, i.e., Intensification Pressure or Lobbying Capacity of intensive agriculture (IAA), to press for Flood protection. The latter pressure increases investments in flood defenses, such as dikes and canals, that lower Crop Damage. These same two drivers also work through two alternate paths of a reinforcing loop (R3) that neutralizes processes that support the paradigm: "Live in Harmony with the River," which competes with the conventional one underlying intensification. Either Intensification Pressure or Lobbying Capacity temper any Pressure for Sustainable Floodplain Management (SFM). SFM refers here to the collection of alternative river management strategies and land uses investigated by the shadow network. Failure to augment SFM reduces the capacity to experimentally modify the shape of water control infrastructure and the landscape to intelligently guide, i.e., Water Steering Capacity, flood waters over the entire floodplain, $i$. e., River-Landscape Controlled Flow. Even brief flood pulses guided over the landscape would severely damage dryland grain monocultures on large farms, depressing crop yields, profits and, ultimately intensification pressure.

Drivers of intensification may eventually be countered (Balancing loop B3a) by their cumulative impacts on Landscape Productivity. Technological intensification leads to soil compaction and loss of organic content, whereas expansion of large farms decreases the spatial complexity of the Landscape Mosaic, lowering biodiversity directly by habitat removal and introduction of invasive species that displace endogenous flora and fauna. Declines in soil organic matter and landscape topographic heterogeneity depress Landscape Water Storage Capacity, thereby increasing vulnerability to drought. Vulnerability to drought and declining soil quality can depress crop yields (B4) over the long run unless artificial sources of water, e.g., pumping, and fertilizers are engaged (Balancing loop B4, and see Fig. A1, Appendix). 
Fig. 4. Processes represented by causal loops supporting either the conventional or the alternative paradigms to river management in the Tisza River Basin.

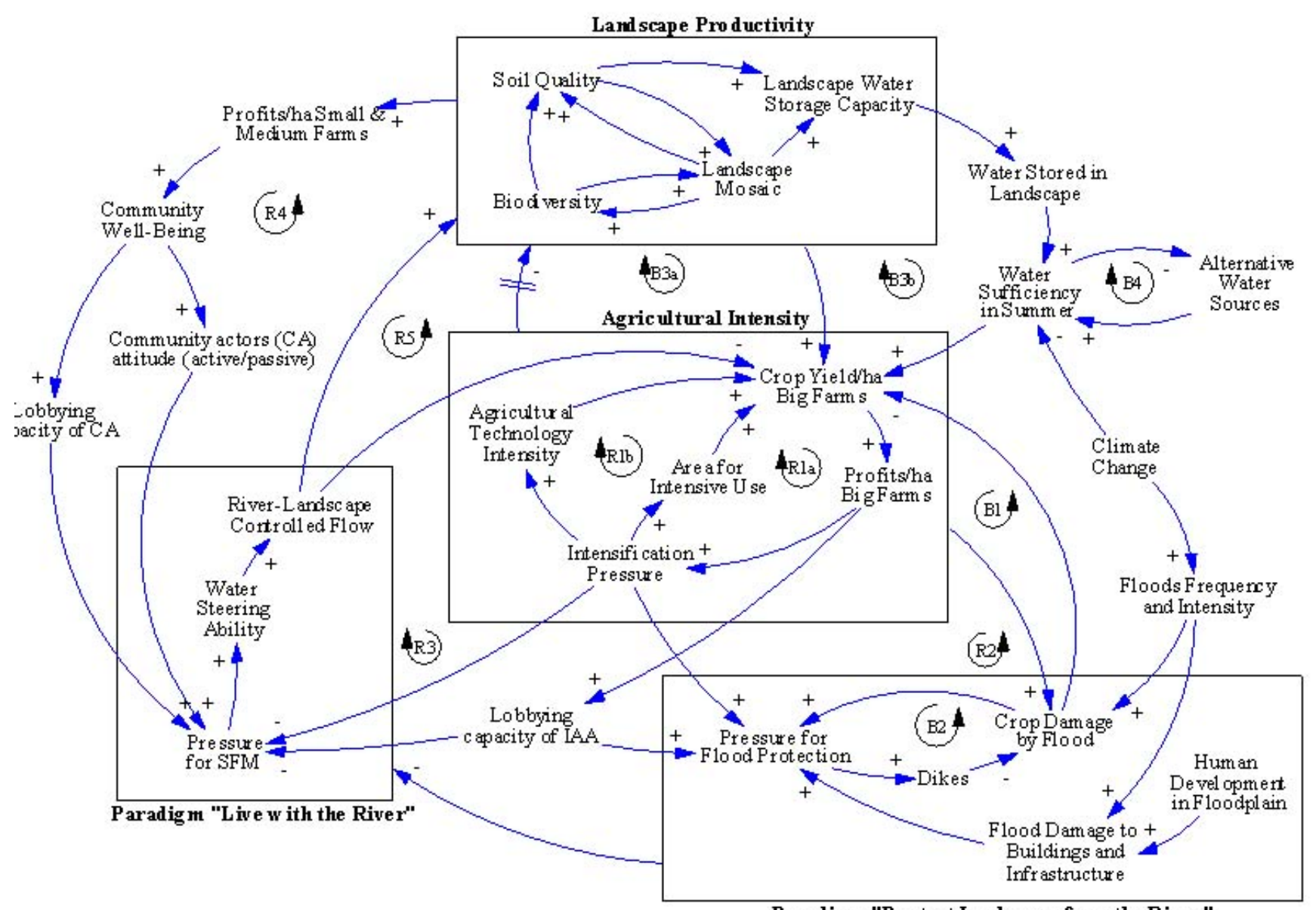

Paradigm "Pro tect Land scape from the River"

While held in check by intensification processes associated with the conventional paradigm: "Protect Landscape from the River," several feedback loops (R4 and R5) embody the potential to augment processes associated with the alternative paradigm. Should pressure for SFM succeed in implementing, even at pilot scales water steering ability that can re-establish River-Landscape Controlled Flows, whose pulses sustain the three-dimensional spatial complexity of the floodplain landscape mosaic. The resultant increases in Landscape Productivity are best translated into profits by Small and Mediumsized farms because their extensive uses can use small habitat patches and the dynamic resource availability of an actively pulsing floodplain.
Consolidation that creates larger farms disrupts the complex mosaic pattern, and their intensive practices are only competitive in a static environment. Increasing profitability of extensive practices coupled with increases in soil quality and biodiversity would boost Community Well-Being, leading to more active community involvement and lobbying for the processes that support the alternative paradigm. These processes in turn could further enhance landscape productivity (R4) and, concomitantly, depress the two key drivers of intensification (R4) as a wetter floodplain decreased the area and intensity of dryland agriculture. 


\section{Oscillating feedback loop dominance and transformability}

The trajectory of a complex adaptive system can shift dramatically depending on which set of feedback loops dominates. Other agricultural production systems have manifested flips between boom and bust modes depending on such oscillating dominance of feedback loops (Jones et al. 2002, Sterman 2000). Figure 4 explicitly excludes many factors and processes inherent in barriers and bridges to transformability so as to outline the overall structure of two such competing sets of feedback loops. Figures in the appendix offer more detail on the structure underlying agricultural intensification (Fig. A1) and extensification (Fig. A2). Development of Fig. 4 helped clarify our group's grasp of some of the structural reasons why processes supporting the conventional paradigm suppress those inherent in the emerging paradigm, thereby blocking transformation to a new RMR. On this foundation we plan to further expand this suite of models and will examine structural interpretations of how all the barriers and bridges in Table 1 operate individually and interact with each other.

\section{DISCUSSION}

\section{Comparison of factors supporting transformability}

Previous assessments (Gunderson et al. 2006, Walker et al. 2006) of social-ecological systems (SES) in North America and Europe found that a variety of factors potentially contribute to transformability. A number of such determinants and components of transformability (Table 2) raise the potential for transition and so correspond to bridges to a more adaptive river management regime (RMR) in the Hungarian reaches of the Tisza River Basin (HTRB). EU subsidies for ecological agricultural practices (Bdg 6) offer incentives to change (D1), such as shifting from dryland farming to extensive practices (Appendix 2) in floodplains exposed to flooding. They also open the door to experiments $(\mathrm{C} 2)$ to hydrologically reconnect the river channel with the floodplain (Bdg 7). Similarly, a number of components (C1-C3) emerged with the establishment of the Shadow Network (Bdgs 1-3), which has since expanded the scope of policy analysis from local to EU scales (D2) as well as a willingness to experiment even if the latter is nascent and weak. However, some critical components and determinants are missing in the HTRB. Loss (Bar 12) of biodiversity, the seed base of local crop varieties (Sendzimir and Flachner 2007), as well as the people and, hence, the knowledge of how to exploit them, has severely drained a critical determinant (D4) that provides the capital around which a new SES can self-organize.

In addition to establishment of a diversity of promising factors, the speed and proper sequence of phases may also indicate the potential to sustain transformation to a stable and resilient new regime (Olsson et al. 2006). So far in the HTRB some of the elements of the first two phases are evident. Over the past decade both building knowledge and networking have laid much of the groundwork for the first phase: Preparing for Change. However, although many champions exist at local and regional levels, e.g., mayor, scientists, and NGO activists, the leadership factor has yet to be established at national to EU scales that can foster trust, understanding, and action across all scales (Bar 10). Similarly, Shadow Network dialogues have substantially developed two streams vital to the second phase, transition, e.g., problem awareness and solutions available. However, neither stream is well-established enough across all geographic or social scales to motivate the third stream: political action.

Elements of change are in the air, even on the ground in some cases, in the HTRB, but is transformation really occurring? Assessing transformability is confounded by complexity both in space and time. The Tisza Basin looks heterogeneous from every perspective: ecological, economic, or sociopolitical. Dramatic business success in one village may be bracketed by others in which most are unemployed. The topography of political awareness is, if anything, even more finely fragmented within the basin, and how far afield understanding reaches, or ought to reach, to affect transformation, is yet one more question. As previously discussed, uncertainty is fed by sources at all levels, including global ones. Timing may also be critical to transformation. Certain factors or streams may have to coexist (Kingdon 1995, Olsson et al. 2006) to successfully negotiate the second phase. However, if certain factors require completion of others to trigger their operation, then the sequencing of necessary factors into a cascading chain may be even more critical (Kinzig et al. 2006). Current tools for assessing transformability list valuable ingredients and coarsely chart a sequence of phases, but sustaining 
Table 2. Factors supporting transformability in social-ecological systems. Sources - 1: Gunderson et al. 2006, 2: Walker et al. 2006.

C1: Development and maintenance of open and flexible epistemic networks; (Bridges 1 and 3)

C2: Diversity of scientific and social learning types operate in parallel; (Bridges 2 and 7)

C3: An arena for discourse; (Bridges 1-3)

C4: Fostering trust through leadership.
D1: Incentives to change vs. not to change, especially subsidies; (Bridges 6 and 10)

D2: Cross-scale awareness and reactivity, including networking within the social-ecological system and between the system and other systems;

(Bridges 1-3)

D3: A willingness to experiment;

(Bridges 1-3, 7)

D4: Reserves and highly convertible assets in human, natural, and built capital.

(Bridge 8) momentum may require a finer reckoning of progress. That may be yet one more talent that enlightened leadership can offer as it measures the pulse of opinion while fostering broad understanding, forging a vision and sustaining political action.

\section{Informal dialogue: appraisal and future prospects}

Conceptual modeling definitely helped us to look across sectors and scales to identify some of the sources of resilience of the current RMR in Hungary that are not readily evident because causation is circular, not linear. It proved especially useful for discussing the potential for transformability when new policy interventions engage the full array of processes that support the regime. Specifically, transformation is unlikely unless the system selforganizes around new policies into a new structure of feedbacks that reinforce each other well enough to displace the feedbacks supporting the current one. That said, although many kinds of tools, from lists to maps to models, can help communicate different perspectives, citizen-science dialogues require more than a diverse toolbox of communication and analysis media. The art of this science includes, among other things, a good sense of when it is time to lay the tools down and simply listen. Our group's dialogue stalled for a time until a deep-seated frustration among our Hungarian partners finally surfaced. As we came to learn, our initiative began in an atmosphere already strained by frustration and "stakeholder fatigue" after more than a decade of contentious debate between shadow network activists and scientists and representatives of local and national authorities (Flachner 2007, in press). The Hungarian members of the author team, along with many local activists, feel that they have compromised too much in such discussions, giving in to requests to balance between demands from different ecological, economic, and social sectors when their experience told them they had not pushed far enough in the direction of ecosystem restoration. For them such compromises dilute commitment to experiment and learn down to trials too modest in scope to ever reconstitute the full productive potential of a floodplain fully exposed to flood pulses. For example, many scenarios balancing ecology with economy precluded any chance to reflood the floodplain. From their perspective, if modeling casual relations across sectors simply frames the dimensions of ineffective compromise, then it lowers adaptive capacity in the long run while appearing to increase learning in the short run. Their fundamental commitment to total restoration, rather than tinkering, emerged as our dialogue proceeded long enough to establish trust and a deeper appreciation of their considerable experience. 
On these foundations real communication can be built, and conceptual modeling tools have something useful to amplify. On such promise we hope to more deeply engage the evolving complexity of the HTRB by aiming beyond a preindustrial past recognizable from maps and traditional lore that inspired us to "invent the future." In a region profoundly different from the past, with novel species in ecosystems and novel expectations in society, how can we experimentally explore what will work and sustain future SESs in the HTRB? The suite of models that helped us articulate a range of hypotheses about how transformation is blocked or facilitated are useful in expanding the informal dialogue of the shadow network to be challenged and improved by many more communities along the Tisza. We plan to do so in four steps: (1) intensive work in English to create template models, (2) training-the-trainers, (3) to apply them in regional dialogues in Hungarian, (4) and incorporating all inputs in generalized models that anchor the suite of smaller-scale models reflecting the diversity of hypotheses generated in the dialogue. However, such conceptual models do not illuminate what happens over time as policies are added or modified, and stress and shock change in frequency and intensity. Deeper insight into transformability emerges as knowledge of structure expands to knowledge about how processes and function influence dynamics (Berkes et al. 2003, Olsson et al. 2004). Relations posited on the basis of intriguing correlations must be made more precise as equations that generate dynamic output and can be challenged by predictions based on historical experience and theory. Toward this end a new suite of quantitative models will be built on the understanding accumulated from development of the current family of conceptual models. Both qualitative and quantitative model development will continue in an adaptive dialogue with local communities along the HTRB, and the insights derived thereby should help to distill this understanding down to narratives that are simple and compelling enough to be useful in steering the political climate toward transformation.

\section{CONCLUSION}

For the past decade a shadow network has catalyzed and sustained informal learning processes exploring alternative river management strategies in the Hungarian reaches of the Tisza River Basin (HTRB). These informal dialogues have generated a wealth of data, experience, and knowledge that bolster the credibility of an alternative river management paradigm: "Live with the River" and its derivative management and livelihood practices and technologies. In our teams' efforts to extend the regional dialogue, group model building exercises proved useful for shadow network discussants to more fully elaborate their hypotheses as to what causal structures underlie the processes that either block or promote transformation of the current river management regime (RMR) to a more adaptive regime based on the alternative paradigm.

The current RMR no longer appears capable of credibly addressing a trap: the failure of conventional river defense engineering to manage rising trends of disordering extreme events, including frequency and intensity of floods, droughts, and water stagnation in the HTRB. These trends may be the long-term results of defensive strategies of the historical RMR, which reflect a paradigm dating back to the Industrial Revolution: "Protect the Landscape from the River." Over the centuries since then it has survived major cataclysms such as war, transition from socialist to democratic market economies, and chronic regional stagnation or decline. Rising flooding trends have shaken but not displaced its central paradigms and development agenda. It appears resilient to current shock and stress levels, mostly on the strength of its established built, political, and economic capital. These suppress the processes that could generate the added adaptive capacity needed to build a new conceptual and methodological foundation for managing the HTRB.

The potential for bridges to an alternative RMR will only be realized if the system self-organizes around the modest experiments that these bridges have so far generated into a new system of feedbacks that reinforce each other along a new trajectory. The current regime's resilience makes that seem unlikely unless its structure is profoundly challenged by deeper shock or stress levels, such as significant cost rises from sources outside that structure that might shift dominance to an alternative set of feedback loops. For example, the momentum of the current prevailing feedback loops would be slowed by cost increases due to energy scarcity, i.e., fossil fuel price spikes, climate change amelioration measures, i.e., carbon taxes, and/or climate change impacts such as damage from drought or floods. The threat of such surprises 
clearly highlights why the resilience of the current RMR is detrimental to its long-term development, sustaining infrastructure, paradigms and practices that prevent it from learning and adapting to increasing uncertainties from global climate and economies.

Until society is convinced by such surprising alerts, only a rigorous and sustained campaign of testing alternative river management policies and land practices can challenge the entrenched assumptions of the conventional paradigm, and thereby, learnby-doing a new methodological basis for an alternative RMR. A significant step up in adaptive capacity will be needed to compare the current, easily demonstrable advantages of intensive grain production concentrated into fixed major land holdings with the future benefits, i.e., social as well as ecological services, of a diversity of alternative practices dispersed over a floodplain of dynamic patches. These alternatives innovate by exploiting rather than resisting water movement, but in such a heterogeneous landscape mosaic such dynamic complexity is difficult to imagine and therefore include as we expand our dialogue regionally. Within a shifting and patchy economic and political context, it contributes to the challenge of conveying a compelling alternative vision that can rally opinion toward transformation.

Responses to this article can be read online at: http://www.ecologyandsociety.org/vol13/iss1/art11/responses/

\section{Acknowledgments:}

We are very grateful to our NeWater colleagues, especially Claudia Pahl-Wostl and Maja Schlueter, for insightful exchanges on resilience and adaptive capacity in river basin management. Critical comments from Anna Vari, Paul Jeffrey, Saskia Werners, and two anonymous reviewers significantly improved earlier versions of the manuscript. The work benefited from discussions with colleagues at the Institute of Environmental Systems Research of Osnabrueck University and at the Department of Ecological Modelling of the Helmholtz-Centre for Environmental Research Leipzig-Halle. This work was supported by the NeWater project (New Approaches to Adaptive Water Management under Uncertainty, Contract no 511179 (GOCE)).

\section{LITERATURE CITED}

Barta K., K. Bódis, T. L. Boga, T. Kiss, R. Kiss, G. Mezísi, I. Pálfai, J. Rakonczai, L. Szlávik, and I. Gy Török. 2000. A Tisza Vidék fejlesztését befolyásoló vízrajzi kockázatok, eríforrások és lehetíségek.

Berkes, F., J. Colding, and C. Folke, editors. 2003. Navigating social-ecological systems: building resilience for complexity and change. Cambridge University Press, Cambridge, UK.

BME ViKöK. 2003. The building of the scientific bases and background of the tasks serving the improvement of the development of tract, country development, flood decreasing and the high water water carrying for phase I of VTT, Budapest University of Technology and Economy, Department of Sanitary and Environmental Engineering, Budapest, Hungary.

Bogár, L. 2007. Hálózatok világuralma [eng. Domination of Networks]. Available online at: $\underline{\mathrm{htt}}$ p://naput.hu/index.php?option $=$ com mtree\&task= viewlink\&link $\mathrm{id}=13$.

Checkland, P. 1981. Systems thinking, systems practice. John Wiley, Chichester, UK.

Checkland, P., and S. Holwell. 1997. Information, systems and information systems. John Wiley, Chichester, UK.

Checkland, P., and S. Holwell. 1998. Action research: its nature and validity. Systemic Practice and Action Research 11(1): 9-21.

Checkland, P., and J. Scholes. 1990. Soft systems methodology in action. John Wiley, New York, New York, USA.

Deets, S. 1996. National discourse and the formation of irreconcilable symbols: the case of the Gabcikovo-Nagymaros dams. Columbia International Affairs Online (CIAO). Available online at: http://w ww. ciaonet. org/conf/iec03/iec03.

Dewulf, A., G. François, C. Pahl-Wostl, and T. Taillieu. 2007. A framing approach to crossdisciplinary research collaboration: experiences from a large-scale research project on adaptive water management. Ecology and Society 12(2):14. [online] URL: http://www.ecologyandsociety.org/vol12/ 
iss2/art14/.

Eden, C., and C. Huxham. 1996. Action research for the study of organizations. Pages 526-542 in S. Clegg, C. Hardy, and W. Nord, editors. The handbook of organization studies. Sage, Beverly Hills, California, USA.

Erös T. 2005. Life history diversification in the middle Danubian fish fauna: a conservation perspective. Archiv für Hydrobiologie Supplement, 158. Large Rivers. 16:289-304.

Erös T. 2007. Partitioning the diversity of riverine fish: the roles of habitat types and non-native species. Freshwater Biology 52:1400-1415.

Erös T., and G. D. Grossman. 2003. Assemblage structure and habitat use of fishes in a central European submontane stream: a patch based approach. Ecology of Freshwater Fish 12:141-150.

European Commission. 2007. The common agricultural policy: a policy evolving with the times. Available online at: http://ec.europa.eu/agriculture/ publi/capleaflet/cap en.htm.

Figeczky, G. 2006. The Hungary national report. World Wide Fund for Nature (WWF) and the Land Use Policy Group. for the Project: Europe's Living countryside: promoting policies for sustainable rural development. Available online at: http://www. lupg.org.uk.

Fitzmaurice, J. 1996. Damming the Danube: Gabcikovo and post-Communist politics in Europe. Westview Press, Boulder, Colorado, USA.

Flachner, Z. 2005. Land use change impact on the carbon balance at highly modified floodplains: a systematic approach for combined emission reduction and land use optimalization. Cereal Research Communications 34(2):189-191.

Flachner, Z. 2007. Criteria for sustainable land management at Tisza Floodplain in the light of multifunctionality. Cereal Research Communications 35(2), in press.

Flachner, Z., and T. Nemeth, editors. 2006. Indicators of vulnerability to floods: questionnaire survey of the Bodrogköz area. Report to United Nations University. Research Institute for Soil and Agrochemistry, Hungarian Academy of Sciences,
Budapest, Hungary.

Fodor, Z. 2005. The channels named "Fok" and Fok-husbanding along the bank of the Hungarian section of the Tisza River. Hungarian Electronic Journal of Sciences. Available online at: http://heja. szif.hu/ENV/ENV-020905-A/env020905a.pdf.

Folke, C., F. Berkes, and J. Colding. 1998. Ecological practices and social mechanisms for building resilience and sustainability. Pages 414-446 in F. Berkes and C. Folke, editors. Linking social and ecological systems. Cambridge University Press, Cambridge, UK.

Gal, B., O. Szirmai, S. Czobel, D. Cserhalmi, and Z. ürmos. 2007. The wetland vegetations as a relict in the agricultural desert of the Hungarian Bodrogköz. Cereal Research Communications 35 (2):405-408.

Gunderson, L. H., C. S. Holling, and S. S. Light, editors. 1995. Barriers and bridges to the renewal of ecosystems and institutions. Columbia University Press, New York, New York, USA.

Gunderson, L. 1999. Resilience, flexibility and adaptive management: antidotes for spurious certitude. Conservation Ecology 3(1):7. [online] URL: http://www.ecologyandsociety.org/vol3/iss1/ art7l.

Gunderson, L. H. 2003. Adaptive dancing: interactions between social resilience and ecological crises. Pages 33-52 in F. Berkes, J. Colding, and C. Folke, editors. Navigating socialecological systems: building resilience for complexity and change. Cambridge University Press, Cambridge, UK.

Gunderson, L. H., S. R. Carpenter, C. Folke, P. Olsson, and G. Peterson. 2006. Water RATs (resilience, adaptability, and transformability) in lake and wetland social-ecological systems. Ecology and Society 11(1):16. [online] URL: http:/ /www.ecologyandsociety.org/vol11/iss 1/art16/.

Heemskerk, M., K. Wilson, and M. PavaoZuckerman. 2003. Conceptual models as tools for communication across disciplines. Conservation Ecology 7(3):8.

[online] URL: http://www.ecologyandsociety.org/vol7/ iss3/art8/. 
Hughes, T., D. Bellwood, C. Folke, R. Steneck, and J. Wilson. 2005. New paradigms for supporting the resilience of marine ecosystems. Trends in Ecology and Evolution 20:7.

Hungarian Ministry of Agriculture and Rural Development 2007. National Rural Development Strategy and Plan. Budapest, Hungary.

Huz, S., D. F. Andersen, G. P. Richardson, and R. Boothroyd. 1997. A framework for evaluating systems thinking interventions: an experimental approach to mental health system change. System Dynamics Review 13(2):149-169.

Jolankai, G., and B. Pataki. 2005. Description of the „Tisza River Project” and its main results. A report on the Tisza River project: real-life scale integrated catchment models for supporting water and environmentalmanagement decisions. Contract No: EVK1-CT-2001-00099. Available online at: http://www.tiszariver.com/main/section6report.pdf

Jones, A. D. Seville, and D. Meadows. 2002. Resource sustainability in commodity systems: the sawmill industry in the northern forest. System Dynamics Review 18:171-204.

Keynes, J. M. 1938. Discussion of R. F. Harrod's presidential address to the Royal Economic Society. Pages X-X in D. E. Moggridge, editor. (1976), Keynes, Fontana/Collins, London, UK.

Kingdon, J. W. 1995. Agendas, alternatives, and public policies. Harper Collins, New York, New York, USA.

Kinzig, A. P., P. Ryan, M. Etienne, H. Allison, T. Elmqvist, and B. H. Walker. 2006. Resilience and regime shifts: assessing cascading effects. Ecology and Society 11(1):20.

[online] URL: http://www.ecologyandsociety.org/vol11/ iss1/art20/.

Koncsos, L. 2006. Modelling of water retention and flood risk in the Upper Tisza and in the Bereg: methods and results. World Food and Agriculture Organization (FAO) Technical Cooperation Program Report: FAO, Rome, Italy.

Koncsos, L., and E. Balogh. 2007. Flood damage calculation supported by inundation model in the Tisza Valley. 32nd Congress of the International
Association of Hydrolic Engineering and Research (IAHR). Venice, Italy, June 2007, in press.

Koncsos, L. and Z. Kozma, Z. 2007. Modeling of floodplain sedimentation on the Hungarian Tisza, in progress: harmonizing the demands of art and nature in hydraulics. 32nd Congress of the International Association of Hydrolic Engineering and Research (IAHR). Venice, Italy, June 2007, in press.

Kundzewicz, Z. W., U. Ulbrich, T. Brücher, D. Graczyk, A. Krüger, G. C. Leckebusch, L. Menzel, I. Pinskwar, M. Radziejewski, and M. Szwed 2005. Summer floods in central Europe: climate change track?" Natural Hazards 36:165-189.

Linerooth-Bayer, J., and A. Vári. 2006. Extreme weather and burden sharing in Hungary. Pages 229-260 in Fairness in adaptation to climate change. W. N. Adger, J. Paavola, S. Huq, and M. J. Mace, editors. MIT Press, Cambridge, Massachusetts, USA.

Linnerooth-Bayer, J.,A. Vari, and M. Thompson. 2006. Floods and fairness in Hungary. Pages 181-203 inM. Verweij and M. Thompson, editors. Clumsy solutions for a complex world: governance, politics and plural perceptions. Palgrave Macmillan, Hampshire, UK.

Magnuszewski, P., J. Sendzimir, and J. Kronenberg. 2005. Conceptual modeling for adaptive environmental assessment and management in the Barycz Valley, Lower Silesia, Poland. International Journal of Environmental Research and Publich Health 2(2):194-203. Available online at: http://www.mdpi.net/ijerph/papers2/ijerph2005020001. pdf.

Magyar Gazdakörök és Gazdaszövetkezetek Szövetsége ( MAGOSZ) 2007. Observations of MAGOSZ on the new Hungary rural development strategic plan (2007-2013). Available online at: $\underline{\mathrm{w}}$ ww.magosz.hu/Rar\$EX00.422ไhir.

Meadows, D. 1970. Dynamics of commodity production cycles. Wright-Allen, Cambridge, Massachusetts, USA.

Mezési, G., I. Keveiné Bárány, and R. Géczy. 1996. The future ecological value of the Hungarian landscape. Acta Geographica Szegediensis Tomus XXXV:21-44. 
Ministry of Environment and Water of Hungary. 2005. Conservation and restoration of the globally significant biodiversity of the Tisza River floodplain through integrated floodplain management. United Nations Development Programme: Global Environment Facility. GEFSEC Project ID \# 1527. Budapest, Hungary.

Ministry of Environmental and Water of Hungary. 2007. New Hungarian rural development programme. Available online at: http://www.fvm.hu

Molnar, G. 2003. Arteri gazdalkodas Magyarorszagon. Page 6 in Proceedings of Szovetseg II evfolyam 2 szam. 17 January 2003, Budapest, Hungary.

Molnar, G. 2005. A Tiszanal. Ekvilibrium Kiadó, Budapest, Hungary. [in Hungarian].

Myers, N. 1998. Lifting the veil on perverse subsidies. Nature 392(6674):327.

Nagy, Z. 2006 The rural development policy in the European Union and in Hungary. Central European Agriculture 7(3):595-599.

Olsson, P., C. Folke, and F. Berkes. 2004. Adaptive co-management for building socialecological resilience. Environmental Management 34:75-90.

Olsson, P., L. H. Gunderson, S. R. Carpenter, P. Ryan, L. Lebel, C. Folke, and C. S. Holling. 2006. Shooting the rapids: navigating transformations to adaptive governance of social-ecological systems. Ecology and Society 11(1):18 [online] URL: http:// www.ecologyandsociety.org/vol11/iss1/art18/.

Pahl-Wostl, C. 2002. Participative and stakeholderbased policy design, evaluation and modeling processes. Integrated Assessment 3(1):3-14.

Pahl-Wostl, C., J. Sendzimir, P. Jeffrey, J. Aerts, G. Berkamp, and K. Cross. 2007. Managing change toward adaptive water management through social learning. Ecology and Society 12(2): 30. [online] URL: http://www.ecologyandsociety.org/vol12/ iss $2 /$ art $30 /$.

Pálfai I., 2006. Aszálygyakoriság és aszálykárok Magyarországon. Hidrológiai Közlöny, Budapest, Hungary. 86(2):63-64.

Richardson, G. 1986. Problems with causal-loop diagrams. System Dynamics Review 2(2):158-170.

Rittel, H., and M. Webber. 1973. Dilemmas in a general theory of planning. Policy Sciences 4:155-169.

Rouwette, E., J. Vennix, and C. Thijssen. 2000. Group model guilding: a decision room approach. Simulation and Gaming 31(3):359-379.

Sawin, B., H. Hamilton, A. Jones, P. Rice, D. Seville, S. Swelitzer, and D. Wright. 2003. Commodity system challenges: moving sustainability into the mainstream of natural resource economies. The Sustainability Institute, Hartland, Vermont, USA.

Scheffer, M., F. Westley, and W. Brock. 2003. Slow response of societies to new problems: causes and costs. Ecosystems 6:493-502.

Sendzimir, J., P. Balogh, A. Vari, and T. Lantos. 2004. The Tisza River Basin: slow change leads to sudden crisis. Pages 261-290 in S. Light, editor. The role of biodiversity conservation in the transition to rural sustainability. NATO ARW Series Science and Technology Policy. Volume 41, ISO Press, Amsterdam, The Netherlands.

Sendzimir, J., and Z. Flachner. 2007. Exploiting ecological disturbance. Pages 213-230 in McNeely and S. Scherr, editors. Farming with nature: the science and practice of ecoagriculture. J Island Press, Washington, D.C., USA.

Sendzimir, J., P. Magnuszewski, P. Balogh, and A. Vari. 2007. Anticipatory modeling of biocomplexity in the Tisza River Basin: first steps to establish a participatory adaptive framework. Environmental Modeling and Software 22 (5):599-609.

Siposs, V., and F. Kiss. 2002. Living with the river. LIFE-nature project in the Tisza Floodplain. Worldwide Fund for Nature, Budapest, Hungary.

Smith, S. E., G. Buettner, F. Szilagyi, L. Horvath, and J. Aufmuth. 2000. Environmental impacts of river diversion: Gabcikovo Barrage system. Journal of Water Resources, Planning, and Management 126(3):138-145.

Smits, A. J. M., P. H. Nienhuis, and R. S. E. W. Leuven. 2000. New approaches to river 
management. Backhuys, Leiden, The Netherlands.

Souren, A. 2000. Weeping rivers: cyanide spills in Romania. Geochemical News 104:14-17.

Sterman J. 2000. Business dynamics: systems thinking and modeling for a complex world. Irwin/ McGraw-Hill, Boston, Massachusetts, USA.

SZáSZ G. 1997. Az éghajlatváltozás és a fenntartható gazdaság kapcsolata a Nagyalföldön. Pages 35-51 in Alföldi Tanulmányok XVI. kötet, pp.35-51.

Szlávik, L. 2003 Az elmúlt másfél évszázad jelentísebb Tisza-völgyi árvizei és az árvízvédelem szakaszos fejlesztése, in Vízügyi Közlemények Különszám (special volume ) IV.

Thompson, M. 1997. Cultural theory and integrated assessment. Environmental Modeling and Assessment 2:139-150.

Thompson, M., R. Ellis, and A. Wildarsky. 1990. Cultural theory. Westview Press, Boulder, Colorado, USA.

Tetlock, P. E. 1985. Accountability: a social check on the fundamental attribution error. Social Psychology Quarterly 48(3):227-236.

Török, K., Z. Botta-Dukát, I. Dancza, I. Németh, J. Kiss, B. Mihály, and D. Magyar. 2003. Biological Invasions 5:349-356.

van der Belt, M. 2004. Mediated modeling: a system dynamics approach to environmental consensus building. Island Press, Washington, D. C., USA.

Van Eeten, M. J. G., and E. Roe. 2002. Ecology, engineering, and management: reconciling ecosystem rehabilitation and service reliability. Oxford University Press, Oxford, UK.

VÁTI Hungarian Public Nonprofit Company for Regional Development and Town Planning (VATI) 2006. Interreg project annual report. Budapest, Hungary. Available online at: http://www .VATI.hu.

VáTI- VIZITERV 2003. Megvalósitási terv a tisza völgyi árapasztó tározó rendsyer I. ütemére valamint a kapcslódó kistérségekben az életfeltételeket javitó intézkedésekre.

Vennix, J. 1996. Group model building: facilitating team learning using system dynamics. Wiley, New York, New York, USA.

Vennix, J. A. M., D. F. Andersen, and G. P. Richardson. 1997. Foreword: group model building, art, and science. System Dynamics Review 13(2): 103-106.

Verhulst, J., Báldi, A., Kleijn, D. 2004. Relationship between land-use intensity and species richness and abundance of birds in Hungary. Agriculture, Ecosystems and Environment 104:465-473.

Vituki, Plc. 2000. Summary of cyanide contamination on the Tisza River. Available online at: http://www.tiszariver.com/index.php?s=results

Walker, B. H, C. S. Holling, S. C. Carpenter, and A. P. Kinzig. 2004. Resilience, adaptability and transformability. Ecology and Society 9(2):5.

[online] URL: http://www.ecologyandsociety.org/vol9/ iss $2 / \operatorname{art} 5 /$.

Walker, B. H., L. H. Gunderson, A. P. Kinzig, C. Folke, S. R. Carpenter, and L. Schultz. 2006. A handful of heuristics and some propositions for understanding resilience in social-ecological systems. Ecology and Society 11(1):13. [online] URL: http://www.ecologyandsociety.org/vol11/iss 1/ $\underline{\operatorname{art13/}}$.

Westley F. 2002. The devil in the dynamics: adaptive management on the front lines. Pages 333-360 in L. H. Gunderson and C. S. Holling, editors. Panarchy: understanding transformations in human and natural systems. Island Press, Washington, D.C., USA.

Whyte, W. F., editor. 1991. Participatory action research. Sage, Newbury Park, California, USA.

World Bank 2006. World development indicators database. Available online at: http://devdata.worldb ank.org/wdi2006/contents/cover.htm. 
Appendix 1. Large and small-scale agriculture in the HTRB

Please click here to download file 'appendix1.pdf'. 
Appendix 2. Extensive agriculture in the HTRB

Please click here to download file 'appendix2.pdf'. 
Appendix 3. Decline in Ecological, Economic and Social Sectors of the HTRB

Please click here to download file 'appendix3.pdf'. 